\title{
Voetballen voor vrede in Noord-Glasgow
}

Jorn Koelemaij

Het Schotse Glasgow kampt al decennialang met bovengemiddeld veel jeugdbendes en geweldsincidenten. De onderlinge rivaliteitsgevoelens tussen buurten, en de territorialiteit die daarmee samenhangt, zijn vandaag de dag nog steeds hardnekkig. Liefdadigheidsinstellingen proberen met behulp van voetbaltoernooien en andere sportactiviteiten een neerwaartse spiraal van negatieve buurteffecten en sociale uitsluiting te voorkomen.

Voor mijn masterscriptie deed ik in het najaar van 2012 onderzoek naar de relatie tussen territorialiteit en sociale uitsluiting onder jongeren. Gedurende een periode van vier maanden ben ik veelvuldig aanwezig geweest in de wijk Possilpark om te praten met jongeren, buurtwerkers en beleidsmakers. Possilpark is een wijk in Noord-Glasgow die hevig gestigmatiseerd wordt door verschillende groepen 'Glaswegians.' De buurt wordt bestempeld als 'gevaarlijk' en 'asociaal', en staat voor velen bekend als 'het centrum van drugshandel.' Volgens de 'Scottish Index of Multiple Deprivation' uit 2012 geldt Possilpark als de op een na meest gedepriveerde wijk van het land. De wijk verschilt echter niet of nauwelijks met de omliggende wijken wat betreft de mate waarin de lokale jeugd, en dan vooral jongens tussen 11 en 17 jaar, bevangen zijn door territorialiteit. Dit betekent dat jongeren zich zo sterk met hun geografisch afgebakende buurt identificeren dat deze door hen geclaimd wordt en daarnaast letterlijk verdedigd wordt tegen anderen. Buurten worden veelal begrensd door een spoorlijn, een park, een brede weg, of in het geval van Possilpark, een kanaal.

De rivaliteit tussen buurten is vaak bepaald door een erfenis uit het verleden. Deze rivaliteit gaat meestal jaren terug en wordt in stand gehouden door de nieuwe generaties die 'negatieve' rolmodellen hebben in vaders, ooms of bekende figuren uit de buurt met een bepaalde reputatie. Hoewel in Glasgow veel rivaliteiten en jeugdbendes voortkomen uit de religieuze tegenstelling tussen protestanten en katholieken, speelt dit in het noorden van de stad vandaag de dag nauwelijks nog een rol. Territorialiteit lijkt vooral te zijn ontstaan op basis van een door de jaren opgebouwde traditie en reputatie. Daarnaast kunnen culturele, etnische en sociaal-economische factoren mogelijk een rol spelen bij het ontstaan ervan. Territorialiteit ontstaat immers eerder in buurten waar de sociale mobiliteit over generaties gering is.

\section{Onzichtbare muren}

Uit de gesprekken die ik voerde bleek dat blootstelling aan geweld voor de jongeren in Possilpark eerder regel dan uitzondering is. Als gevolg hiervan zijn velen vaak bang om zich buiten de onzichtbare muren, die hun eigen veilige buurt begrenzen, te begeven. Als dit al gebeurt, wordt er vaak voor gekozen dit met een grote groep te doen. Ook jongeren die stellig verklaarden niets met deze territoriale rivaliteit te maken wilden hebben ontkomen er niet aan. Dit bleek toen een van mijn respondenten een aantal weken na ons interview plotseling door een aantal leeftijdsgenoten in een aangrenzende buurt belaagd werd en met messteken moest worden afgevoerd naar het ziekenhuis.

\section{Blootstelling aan geweld is voor jongeren in Possilpark eerder regel dan uitzondering}

De diepgewortelde cultuur van territorialiteit heeft een grote impact op het sociale perspectief onder jongeren in Noord-Glasgow. Sociale netwerken en mobiliteit worden sterk belemmerd door het feit dat hun leven zich noodgedwongen zo lokaal afspeelt. Daarnaast zijn er nog talloze andere negatieve buurteffecten op te noemen waar territorialiteit een wederkerig effect op lijkt te hebben. Door de over het algemeen uniforme en lokaal georiënteerde sociale contacten bestaat het risico van 


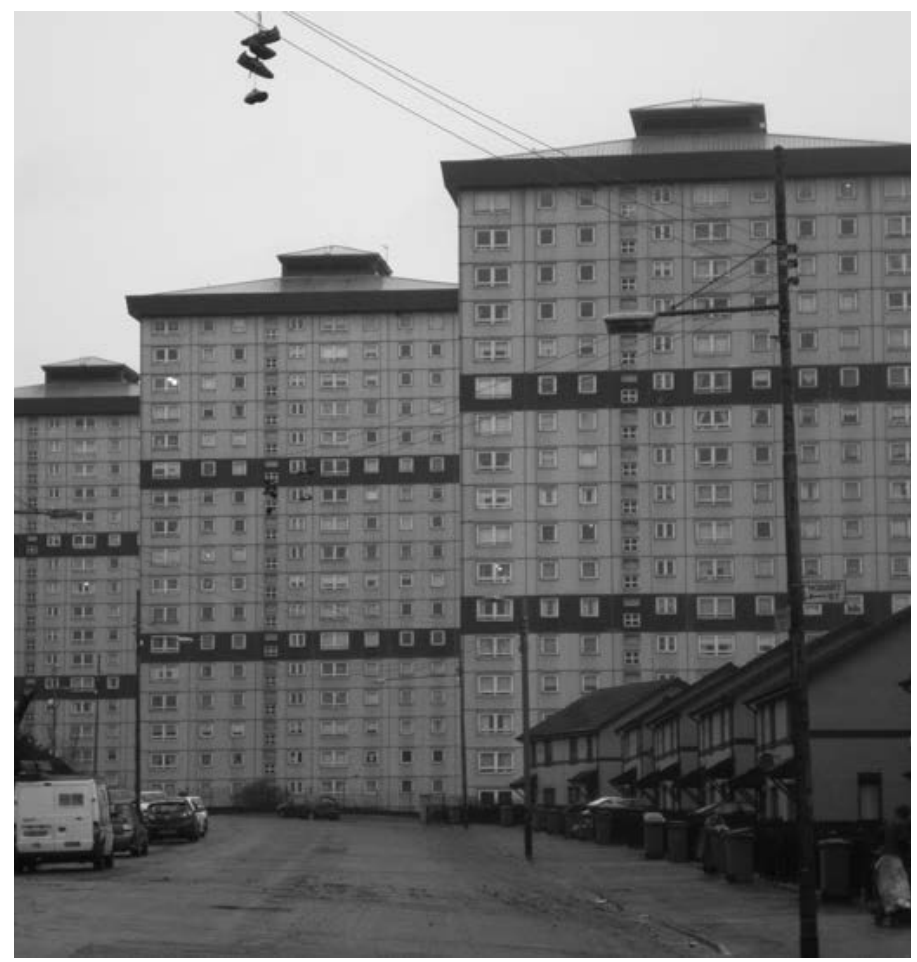

De Westercommon flats zijn de grote blikvanger in het westen van Possilpark, dat verder voornamelijk uit laagbouw bestaat. Foto: Jorn Koelemaij

'sociale besmetting'. Dit wil zeggen dat door groepsdruk afwijkend gedrag al snel als de norm wordt beschouwd. Verder wordt het eerder genoemde negatieve stigma dat in heel Glasgow aan Possilpark kleeft niet snel bijgesteld wanneer deze jongeren niet of nauwelijks in contact komen met leeftijdsgenoten uit andere delen van de stad. Dit alles draagt negatief bij aan de mate van sociale uitsluiting onder de meerderheid van de individuen uit deze groep. Veel jongeren hebben amper een idee van de mogelijkheden die de stad hen te bieden heeft op het gebied van werk, recreatie en educatie, of lijken zich te hebben neergelegd bij het feit dat veel dingen niet voor hen zijn weggelegd.

\section{De diepgewortelde cultuur van territorialiteit heeft grote impact op het sociale perspectief}

\section{Voetbal als verbindende factor?}

Toch lijkt er voorzichtig aan verandering te komen in de situatie in NoordGlasgow. Dit is in grote mate te danken aan de organisatie 'A\&M Training', een door de gemeente en andere partners gefinancierde liefdadigheidsinstelling die erop gericht is jongeren positieve impulsen te geven en ze te stimuleren in hun persoonlijke ontwikkeling. Eén van de belangrijkste activiteiten die door A\&M georganiseerd wordt is de 'Friday Night Football League': een competitie waarbij verschillende buurten het op vrijdagavond tegen elkaar opnemen op het voetbalveld. Dit vindt plaats onder leiding van een coach en een scheidsrechter, beiden afkomstig van A\&M. Op deze manier kunnen jongeren elkaar op een informele manier beter leren kennen, en leren ze op een sportieve en respectvolle manier met elkaar om te gaan. De ambitie van $A \& M$ is dat er zo meer wederzijds vertrouwen ontstaat en geweldsincidenten voortkomend uit territorialiteit op den duur zullen afnemen. Het heeft er alle schijn van dat deze projecten inderdaad hun vruchten afwerpen. De bedenkelijke gedragsnormen onder jongeren in een buurt als Possilpark worden langzaam maar zeker verbeterd. Bij ernstige misdragingen worden jongeren bijvoorbeeld voor kortere of langere tijd geschorst en dus uitgesloten van deelname. De competitie heeft inmiddels zoveel status verworven in Possilpark dat het gros van de deelnemers er alles aan doet dit te voorkomen. Op deze manier leren de soms nogal opvliegende en grofgebekte jongeren zichzelf steeds beter te beheersen, ook buiten het voetbalveld. Waar voetbalwedstrijden tussen lokale clubs elders in de wereld juist vaak zorgen voor territorialiteit, rivaliteit en agressie, leidt de door A\&M opgezette competitie er dus juist toe dat de verstoorde verhoudingen enigszins worden genormaliseerd.

Hoewel niet alle jongeren uit - bijvoorbeeld - Possilpark door A\&M bereikt worden, lijkt deze aanpak inderdaad succesvol. De meerderheid van de jongeren is enthousiast en dit leidt in veel gevallen tot persoonlijke ontwikkeling: zelfbeheersing, zelfvertrouwen en respect voor de ander zijn slechts een aantal voorbeelden hiervan. In de buurten waarin A\&M actief is, zijn het aantal meldingen van vandalisme, overlast en alcoholgebruik onder jongeren bovendien aantoonbaar afgenomen.

Ten tijde van mijn onderzoek was het helaas nog steeds het geval dat de jeugd uit Possilpark, hoewel ze klachten hadden over de kwaliteit van de sportfaciliteiten in eigen wijk, weigerden om gebruik te maken van het veel betere veldje in het nabijgelegen Springburn. De doelen die A\&M zich stelt zijn dan ook ambitieus: de sociale problematiek is dermate diepgeworteld dat de problemen niet binnen een paar jaar kunnen worden opgelost met een voetbalcompetitie. Toch is het van fundamenteel belang voor beleidsmakers in steden overal ter wereld om territorialiteit waar mogelijk te signaleren en aan te pakken. Met behulp van sport kan dit probleem aan banden worden gelegd. Behalve het normaliseren van ruimtelijke verhoudingen kan sport tevens zorgen voor persoonlijke ontwikkeling. Hierdoor zijn jongeren uit achterstandsbuurten gemakkelijker in staat contact te leggen met mensen buiten hun eigen, veilig begrensde, wereldje. Dit zal helpen sociale uitsluiting op veel manieren tegen te gaan, terwijl het sociale mobiliteit juist zal bevorderen.

\section{Jorn Koelemaij (Jorn.Koelemaij@UGent.be) is al academisch assistent en promovendus Sociale en Economische Geografie verbonden aan de Universiteit Gent.}

\section{Literatuurselectie}

Kintrea, K., J. Bannister en J. Pickering (2010) Territoriality and

disadvantage among young people: an exploratory study of six British neighbourhoods. Housing and the Built Environment, nr. 25, pp. 447-465

Kintrea, K. en N. Suzuki (2008) Too much cohesion? Young people's territoriality in Glasgow and Edinburgh. In: Flint, J. en D.

Robinson (2008) Community Cohesion in Crisis? Bristol: The Policy Press. pp. 199-218. 


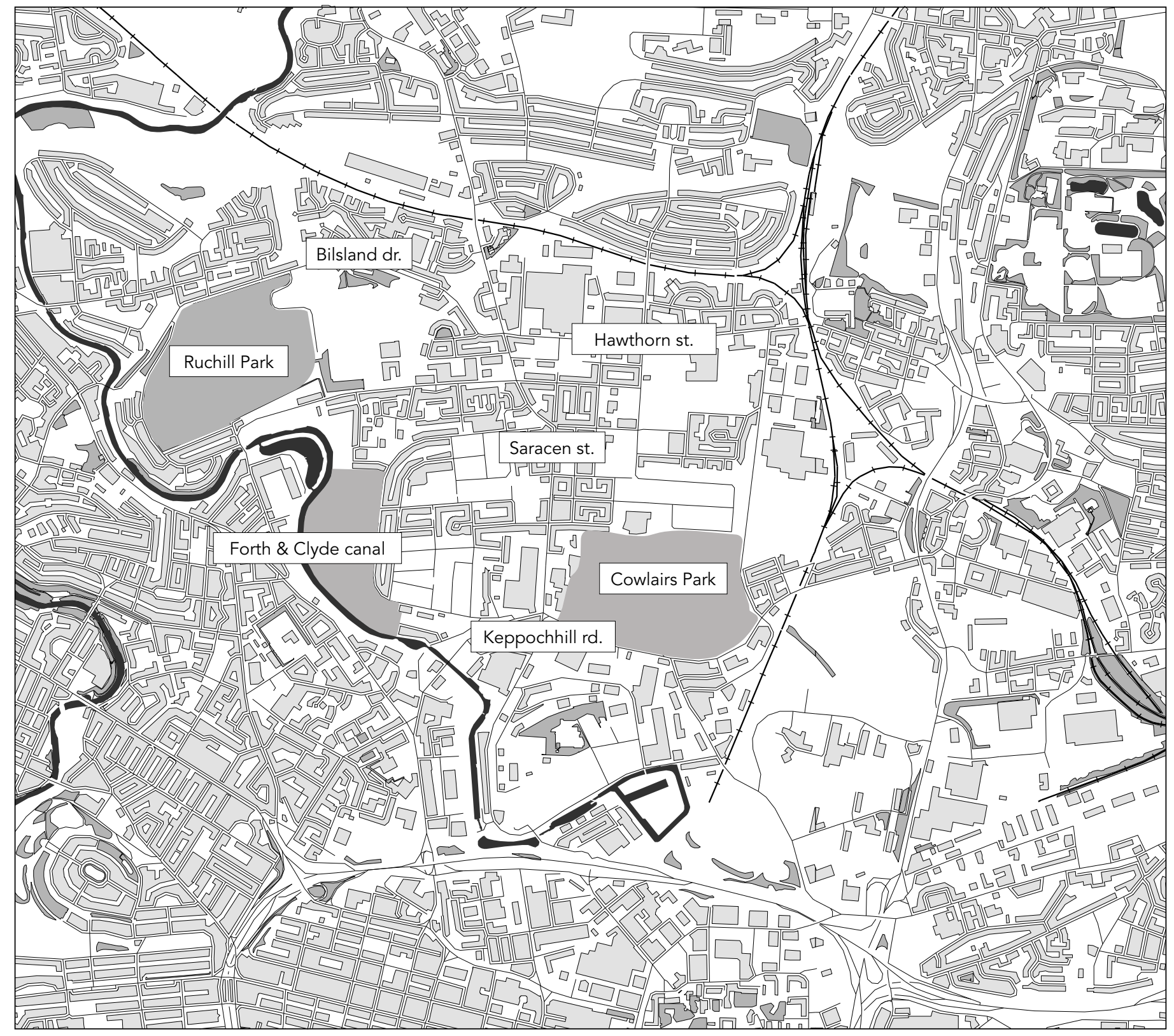

De ligging van Possilpark, net ten noorden van het centrum van Glasgow. Bron: Ordnance Survey OS OpenData.

Door: Jorn Koelemaij en Lars van Hoeve

\begin{tabular}{|c|c|c|}
\hline \multicolumn{3}{|l|}{ Legenda } \\
\hline & Bebouwing & (1) \\
\hline & & 1:20.000 \\
\hline & Groen / park & \\
\hline & Straten & \\
\hline$+1111+$ & Spoor & \\
\hline
\end{tabular}

Possilpark is niet alleen mentaal, maar ook fysiek duidelijk afgebakend door middel van duidelijke grenzen. Zoals op deze kaart te zien is vormt het Forth \& Clyde Canal de westelijke grens, Keppochhill Road de zuidelijke, en zijn Bilsland Drive en Hawthorn Street de noordgrens. Aan de oostelijke rand vormt de spoorrails de fysieke barrière. Verder bevinden zich aan de randen van de wijk een drietal matig onderhouden parken. Op de kaart valt verder op hoe laag de dichtheden in Possilpark zijn vergeleken met het centrum van de stad. Zowel ten westen als ten oosten van Saracen Street (de centrale winkelstraat) liggen veel open, braakliggende stukken grond. 